\title{
The role of pneumonia and secondary bacterial infection in fatal and serious outcomes of pandemic influenza $\mathrm{a}(\mathrm{H} 1 \mathrm{~N} 1) \mathrm{pdm} 09$
}

Chandini Raina Maclntyre ${ }^{1}$, Abrar Ahmad Chughtai ${ }^{2 *}$, Michelle Barnes², Iman Ridda², Holly Seale ${ }^{2}$, Renin Toms ${ }^{2}$ and Anita Heywood ${ }^{2}$

\begin{abstract}
Background: The aim of this study was to estimate the prevalence of pneumonia and secondary bacterial infections during the pandemic of influenza A(H1N1)pdm09.

Methods: A systematic review was conducted to identify relevant literature in which clinical outcomes of pandemic influenza A(H1N1)pdm09 infection were described. Published studies (between 01/01/2009 and 05/07/2012) describing cases of fatal or hospitalised A(H1N1)pdm09 and including data on bacterial testing or co-infection.

Results: Seventy five studies met the inclusion criteria. Fatal cases with autopsy specimen testing were reported in 11 studies, in which any co-infection was identified in 23\% of cases (Streptococcus pneumoniae 29\%). Eleven studies reported bacterial co-infection among hospitalised cases of A(H1N1)2009pdm with confirmed pneumonia, with a mean of 19\% positive for bacteria (Streptococcus pneumoniae 54\%). Of 16 studies of intensive care unit (ICU) patients, bacterial co-infection identified in a mean of $19 \%$ of cases (Streptococcus pneumoniae 26\%). The mean prevalence of bacterial co-infection was $12 \%$ in studies of hospitalised patients not requiring ICU (Streptococcus pneumoniae 33\%) and 16\% in studies of paediatric patients hospitalised in general or pediatric intensive care unit (PICU) wards (Streptococcus pneumoniae 16\%).

Conclusion: We found that few studies of the 2009 influenza pandemic reported on bacterial complications and testing. Of studies which did report on this, secondary bacterial infection was identified in almost one in four patients, with Streptococcus pneumoniae the most common bacteria identified. Bacterial complications were associated with serious outcomes such as death and admission to intensive care. Prevention and treatment of bacterial secondary infection should be an integral part of pandemic planning, and improved uptake of routine pneumococcal vaccination in adults with an indication may reduce the impact of a pandemic.
\end{abstract}

Keywords: Influenza A(H1N1)pdm09, Bacterial infection, Pneumonia, Respiratory infections hospitalization

\footnotetext{
* Correspondence: journal.health.au@gmail.com

${ }^{2}$ School of Public Health and Community Medicine, Faculty of Medicine,

UNSW Medicine, the University of New South Wales, Samuels Building, Room

209, Sydney, NSW 2052, Australia

Full list of author information is available at the end of the article
}

(c) The Author(s). 2018 Open Access This article is distributed under the terms of the Creative Commons Attribution 4.0 International License (http://creativecommons.org/licenses/by/4.0/), which permits unrestricted use, distribution, and reproduction in any medium, provided you give appropriate credit to the original author(s) and the source, provide a link to the Creative Commons license, and indicate if changes were made. The Creative Commons Public Domain Dedication waiver (http://creativecommons.org/publicdomain/zero/1.0/) applies to the data made available in this article, unless otherwise stated. 


\section{Background}

Influenza pandemics cause morbidity and mortality from both direct viral effects, which tend to present early (within the first few days), and secondary bacterial complications, which tend to present later (after the first week). Evidence of influenza predisposing to bacterial co-infection is seen in seasonal influenza epidemics, past pandemics, pathology studies and animal models [1-8]. Infection with influenza disrupts the respiratory tract by direct pathogenic effects, which then predisposes to bacterial secondary infection. Conversely, bacterial pathogens in the respiratory tract may also predispose to influenza and other viral infection [9]. During the 1918 pandemic, bacterial pneumonia was a major cause of morbidity and mortality, as shown by studies at the time as well as retrospective study of pathology specimens $[10,11]$. At that time, antibiotics were not widely available as they are now, and it is thought that the high observed mortality rate was partially due to the inability to treat secondary bacterial sepsis. The most important bacterial co-infections during an influenza pandemic $S$. pneumoniae, $H$. influenzae, S. aureus, and group A Streptococcus $(1,4)$. However, two early reviews of severe cases of 2009 pandemic influenza A (H1N1) showed no evidence of bacterial pneumonia among 30 hospitalized patients with laboratory-confirmed cases in California (5) and 10 intensive-care patients in Michigan (6). These reports might have led to a perception that bacterial co-infections played a limited role or no role in pandemic influenza deaths in 2009.

The aim of this study was to estimate the prevalence of pneumonia and secondary bacterial infections during the 2009 pandemic of influenza A(H1N1)pdm09.

\section{Methods}

\section{Search strategy}

A systematic review was conducted according to the Preferred Reporting Items for Systematic Reviews (PRISMA) [12].We sought primary studies that presented quantitative data of invasive bacterial co-infection in influenza $\mathrm{A}(\mathrm{H} 1 \mathrm{N1}$ )pdm09 patients, defined as isolation of a bacterial pathogen from a sterile site. Databases searched included Medline, Pre-Medline, EmBASE and LILACS. The search strategy included a combination of Medical Subject Headings (MeSH) and text words to improve the identification of relevant publications in which bacterial co-infection was not necessarily the primary outcome of interest. The World Health Organisation (WHO) advised on the use of the standardised nomenclature influenza A(H1N1)pdm09 in October 2011 [13]. Prior to this time, various names were used to describe the pandemic virus. As such, a broad search strategy was developed to identify relevant literature in which clinical outcomes of influenza $\mathrm{A}(\mathrm{H} 1 \mathrm{N1})$ pdm09 infection were described.
The Medline search included a combination of two searches. The first included the MeSH term influenza A H1N1 subtype OR text words influenza or flu adjacent to $\mathrm{H} 1 \mathrm{~N} 1 /$ pandemic/swine AND the MeSH term bacterial infections OR text words bacteria*, streptococcus, pneumococcus or staphylococcus adjacent to pneumonia, secondary, infection or evidence. The second search strategy included the influenza search terms and a combination of severity terms including fatal, severe, death, mortality, morbidity, hospitalisation, critical and admitted. The same search terms were applied to the other databases, after ensuring the $\mathrm{MeSH}$ terms of the relevant search terms were consistent across databases. Searches were limited to human studies, published in the English language between 01/01/2009 and 05/07/2012 or accessible online, ahead of print within this timeframe. Handsearching of the reference lists of included studies and relevant reviews were also undertaken to identify other relevant papers.

\section{Inclusion and exclusion criteria}

We included all studies of influenza A(H1N1)pdm09 which report bacterial infections (any sterile site) in influenza A(H1N1)pdm09 cases. Studies including only specific at-risk populations such as transplant or oncology patients or pregnant women were excluded. We included published English language papers of observational studies reporting on $\geq 10$ influenza $\mathrm{A}(\mathrm{H} 1 \mathrm{~N} 1)$ pdm09 patients. Case reports and small case series of $<10$ patients were also excluded.

Included cases were either fatal or hospitalised cases of confirmed or probable influenza A(H1N1)pdm09 confirmed by PCR or culture. Probable cases (13/75 studies) included those with positive influenza A serology during 2009-2010, but not testing of subtype.

However, studies which included a mixed cohort of influenza $\mathrm{A}(\mathrm{H} 1 \mathrm{~N} 1)$ pdm09 and other laboratory-confirmed influenza strains or influenza negative cases were only included if clinical outcomes could be distinguished between influenza $\mathrm{A}(\mathrm{H} 1 \mathrm{~N} 1) \mathrm{pdm} 09$ and other confirmed strains. We excluded studies which described ambulatory influenza $\mathrm{A}(\mathrm{H} 1 \mathrm{~N} 1) \mathrm{pdm} 09$ cases, including notifications, clinic visits or Emergency Department visits with no sub-group analysis in which hospital admission or death of patients was described.

For included studies, the definition of co-infection was broad and included any study reporting either pulmonary infection or site unspecified with or without data on bacterial type tested, or specimen tested, including those reporting negative findings. We excluded studies reporting suspected bacterial pneumonia on the basis of clinical findings alone and studies which tested specimens for presence of co-infection with respiratory viruses only. Studies reporting contamination of endotracheal tubes 
only and those in which patients were recruited on the basis of bacterial infection were excluded if no data on other results were reported. We present the number of cases of reported pneumonia and those requiring mechanical ventilation as per the investigators definition.

\section{Data extraction and assessment}

Five reviewers (AH, MB, RT, IR,, HS,) with experience in conducting systematic reviews independently reviewed the titles and abstracts to identify potentially relevant papers. All potentially relevant papers were read by two reviewers $(\mathrm{AH}, \mathrm{MB})$ to determine those which met the selection criteria. The results of the search strategy are shown in Fig. 1. An identical data extraction template was used by all reviewers to extract the clinical outcomes, diagnostic data and treatment. Clinical outcomes included the diagnosis of bacterial co-infection, pneumonia, and death. Treatment included mechanical ventilation and use of antibiotics. Diagnostic data included determination of pneumonia and bacterial testing. We also extracted methodological details of the relevant studies including study design, study location and methods of case ascertainment. To ensure consistency in data extraction, each study was independently data extracted by two reviewers. All findings, including discrepancies between reviewers were discussed with an independent senior reviewer (CRM).

We report bacterial findings separately from pulmonary specimens when available. When site of specimen is not specified or combined, this is reported as such. We report the percentage of tested cases positive for bacteria when available. The variability of the available data precluded the aggregation of results in a quantitative meta-analysis. Results of the studies are summarised and a critically evaluation and interpretation provided. We present results separately for fatal cases, hospitalised cases with confirmed pneumonia, cases admitted to intensive care units (ICU) and hospitalised cases admitted to general wards including criteria for admission if reported. Pneumonia, hospital admission and ICU admission were accepted according to classification in the reviewed papers.

\section{Results}

\section{Summary of included studies}

A total of 7845 studies were identified on the 2009 pandemic, of which 1444 articles were initially identified from our search of studies potentially about both influenza $\mathrm{A}(\mathrm{H} 1 \mathrm{~N} 1)$ pdm09 and bacterial infection. After removal of duplicates, non-human, non-English language, and non-influenza A(H1N1)pdm09 studies, 863 articles remained and abstracts were reviewed. Of those, 350 full papers were reviewed for relevance and 75 studies met the inclusion criteria. The PRISMA diagram of the study selection is shown in Fig. 1.
Reporting of patient clinical outcomes, bacterial testing and bacterial findings varied widely in the included published studies. It was not clear in many studies if pneumonia was community or hospital acquired. The studies also varied in their methodologies and proportion of patients tested, as well as reporting of bacterial testing. Samples and time of sampling were not adequately described in most of the studies.

Eleven studies were on fatal cases, including eight reporting autopsy results and three studies reporting bacterial findings from medical record reviews of notified deaths of confirmed influenza $\mathrm{A}(\mathrm{H} 1 \mathrm{~N} 1) \mathrm{pdm} 09$. The remaining studies reported bacterial findings from hospitalised cases. Figure 2 shows the average prevalence of bacterial infection in fatal, ICU admitted, general ward admitted and paediatric patients.

Bacterial co-infection among fatal cases of $A(H 1 N 1) 2009 p d m$ Eleven studies reported evidence of bacterial co-infection of fatal confirmed cases of influenza A(H1N1)pdm09 occurring between April 2009 and May 2010 [1, 2, 14-22]. Eight studies reported autopsy results, including 8 autopsy case series $[1,2,16-19,21,22]$ and 3 reporting bacterial findings from medical records reviews only $[14,15,20]$. Five studies were based in the USA $[1,2,15,16,18]$ while the others were from Mexico [14], Estonia [22], Brazil [17], the United Kingdom [19], Korea [20] and Japan [21].

Influenza $\mathrm{A}(\mathrm{H} 1 \mathrm{~N} 1)$ pdm09 infection was confirmed by reverse transcriptase polymerase chain reaction (rtPCR) in either ante-mortem nasopharyngeal swab or post-mortem lung tissue specimens for all cases in all studies. Case definitions for an included fatal case reflected national surveillance reporting and/or autopsy requirements during the pandemic period and enhanced surveillance for the identification of fatal cases included the review of the death certificate registries for influenza as a cause of death.

The study details, bacterial testing and bacterial findings are summarised in Table 1 . Where data were available, $44-100 \%$ of cases were hospitalised before death, including $55-100 \%$ in ICUs, with $35-100 \%$ requiring mechanical ventilation support during their hospitalisation and $25-94 \%$ of patients with clinical and/or autopsy evidence of pneumonia (viral or bacterial). From chart reviews, positive bacterial growth ranged from 2 to $38 \%$ (mean bacterial 23\%) [9] of autopsied cases. Of the total coinfection cases, $29 \%$ were Streptococcus pneumoniae. The overall rate of bacterial infection was significantly higher in fatal cases compared to nonfatal cases (OR 1.71, 95\% CI 1.33 to 2.20). The Korean study of standardised case reports of $\mathrm{A}(\mathrm{H} 1 \mathrm{~N} 1)$ pdm09-associated deaths identified during a period of active surveillance estimated ILI case-fatality rate to be 16 per 100,000 cases [20].

The lowest proportion of co-infection was reported in the first 100 confirmed deaths in Mexico [14] where 94\% 


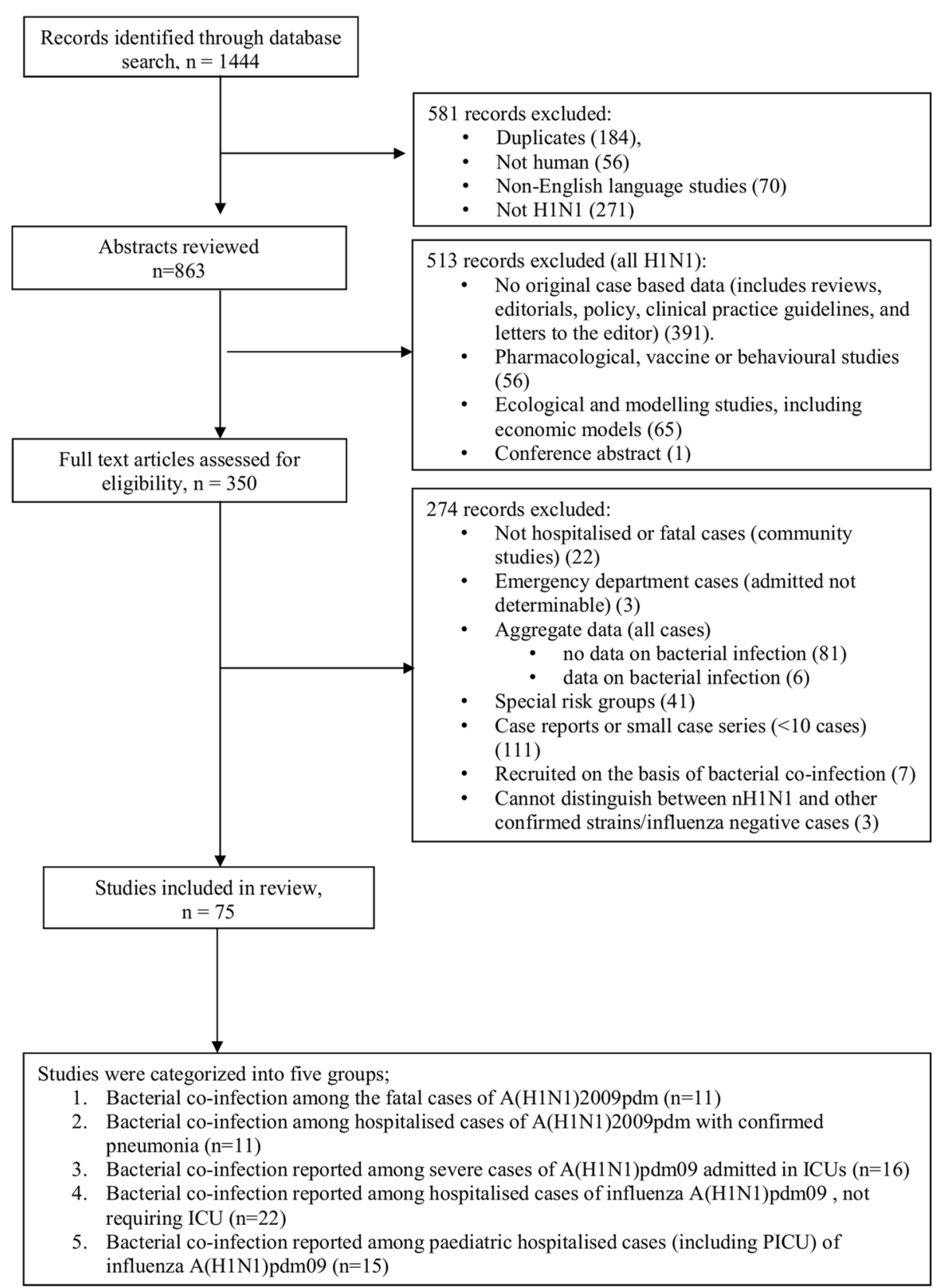

Fig. 1 Study diagram

of patients had multiple foci of pneumonia (based on imaging) and $84 \%$ required mechanical ventilation, and only 2 cases had positive bacterial cultures (Staphylococcus epidermidis and Staphylococcus hominis). Of the eight autopsy case series, 3 studies tested lung tissue specimens for evidence of bacterial infection in all included subjects [16-18] and identified bacterial co-infection diagnosed either before or after death in between 29 and $43 \%$ of fatal cases [16-18]. The highest proportion of culture positive bacterial co-infection from autopsy samples (38\%) was reported by Tamme [22].
The reported post-mortem bacteriologic samples included culture, immunohistochemistry and PCR. No studies gave a complete picture of pulmonary bacterial coinfection during the clinical course and corresponding post-mortem findings. Bacterial co-infection identified prior to death was identified from clinically driven testing and no studies had a standardised testing protocol for all included fatal cases. On this basis, bacterial infection complicating $\mathrm{A}(\mathrm{H} 1 \mathrm{~N} 1)$ pdm09 ranged from 5 to $14 \%$ of fatal cases in the four studies $[1,17,21,22]$ reporting data from clinical testing prior to death (Table 1). Specimens 


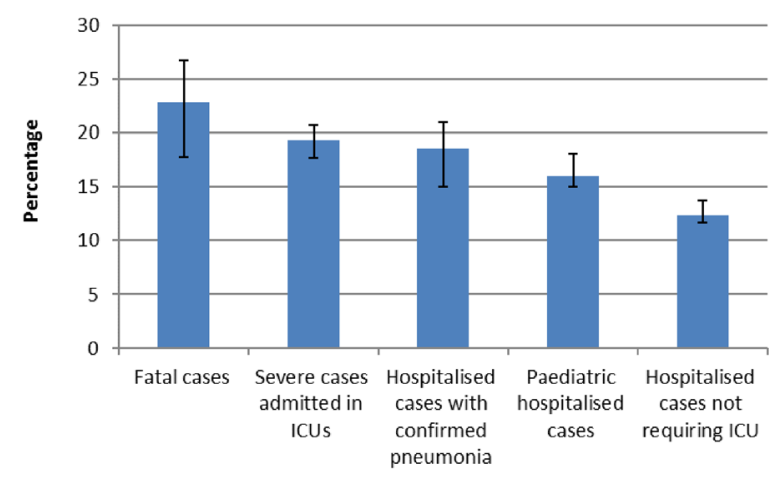

Fig. 2 Average prevalence of bacterial infection in fatal, ICU admitted, general ward admitted and paediatric patients

obtained included sputum, bronchial aspirates and bronchoalveolar lavage, but no studies reported details of testing conducted prior to death, including the proportion tested, or the types of bacteria tested for.

\section{Bacterial co-infection among hospitalised cases of A(H1N1)2009pdm with confirmed pneumonia}

Eleven studies reported on influenza A(H1N1)pdm09 among hospitalised cases with evidence of pneumonia and are summarised in Table 2. Pneumonia was largely defined based on radiological findings in these studies. Any positive bacterial testing was reported in 9/11 studies and positive bacterial growth was ranged from 0 to $47 \%$ (mean 19\%). Streptococcus pneumoniae was the most commonly isolated pathogen (54\%). In these 9 studies, Acinobacter baumanii was the next most commonly identified bacteria (5-21\%), followed by MRSA (3-6\%), S. pneumoniae $(2-4 \%)$ and $K$. Pneumonia in (1-8\%). Of the 11 studies, 2 reported no evidence of bacterial co-infection in their cohort of patients $[4,23]$, however, neither reported the proportion of patients tested. The study conducted in Mexico early in the pandemic [23] isolated ventilator-associated bacteria in 4 (22\%) cases, with Acinetobacter baumannii, Achromobacter xylosoxidans, methicillin-resistant Staphylococcus aureus, and Escherichia coli identified.

Six studies reported use of antibiotics prior to specimen collection in subjects with bacterial co-infection in $21-22 \%$ of those tested [23, 24]. One study reported factors associated with acute respiratory distress syndrome (ARDS) or death, with the ARDS-death group more likely to have bacterial co-infections than patients who survived without ARDS or had mild disease [25]. Specimens included sputum, bronchial aspirate, pleural fluid, urine and blood with testing mainly being bacterial culture, but also multiplex PCR assay for respiratory bacterial panels (for detection of Legionella pneumophila, Chlamydophila pneumoniae, and Mycoplasma pneumoniae) and Binax NOW, an in vitro immunochromatographic assay for Streptococcus pneumonia. However, the
mPCR assay did not test for S. pneumoniae in one study and the authors could not report the presence of this organism [23].

\section{Bacterial co-infection reported among severe cases of A(H1N1)pdm09 admitted to ICUs}

Sixteen studies reported on influenza A(H1N1)pdm09 cases admitted to ICU wards and are summarised in Table 3. Criteria for admission to ICU varied in the included studies, including acute respiratory distress (ARD) $[26,27]$, acute respiratory failure $[28,29]$, required mechanical ventilation (MV) $[5,30,31]$ or $\mathrm{MV}$ or low O2/IV vasoconstrictive drugs [32, 33], MV or ECMO [34] or admitted with no criteria provided [35-41]. Eleven studies included only PCR confirmed A(H1N1)pdm09 cases, while three included probable cases $[31,39,40]$ and another three included both probable and suspected cases $[5,33,34]$. Any positive bacterial testing was reported in 12 studies and bacterial co-infection was identified in 1$43 \%$ of cases (mean bacterial 19\%, Streptococcus pneumoniae $26 \%$ ). One study assessed differences in mortality outcomes based on secondary bacterial pneumonia. In a large study involving admissions to 35 ICUs for ILI and ARF requiring mechanical ventilation in Argentina $(n=337), 24 \%$ of included patients had bacterial pneumonia on admission, $8 \%$ with S. pneumoniae [5]. S.pneumoniae co-infection was associated with higher mortality (OR 2.72 95\% CI 1.057.06), despite concurrent antibiotic treatment on admission [5]. A Canadian study $(N=168)$ attributed secondary bacterial infection as a leading cause of death in the 29 (17.3\%) fatalities that occurred in this cohort [33].

\section{Bacterial co-infection reported among hospitalised cases of influenza $A(\mathrm{H} 1 \mathrm{~N} 1)$ pdm09, not requiring ICU}

Twenty two studies reported on hospitalised influenza $\mathrm{A}(\mathrm{H} 1 \mathrm{~N} 1) \mathrm{pdm} 09$ cases (not requiring ICU) and are summarised in Table 4. Almost all studies include patients admitted to general wards, however some were transferred to ICU during the course of treatment. Most of the studies (19/22) reported bacteria testing and any positive bacterial growth was reported in $1.6-76 \%$ cases (mean bacterial 12\%, Streptococcus pneumoniae 33\%). The number of patients with S.pneumoniae co-infection varied from 1 to $31 \%$ depending on site of sample. Palacios et al. conducted a study in Argentina and bacteria was found in $76 \%$ of nasopharyngeal samples (152/199), of which Streptococcus pneumoniae was isolated in 31\% $(62 / 199)$ samples [42].

\section{Bacterial co-infection reported among paediatric hospitalised cases (including PICU) of influenza A(H1N1)pdm09}

Fifteen studies reported on admitted paediatric influenza $\mathrm{A}(\mathrm{H} 1 \mathrm{~N} 1) \mathrm{pdm} 09$ cases, including 11 to any hospital ward 


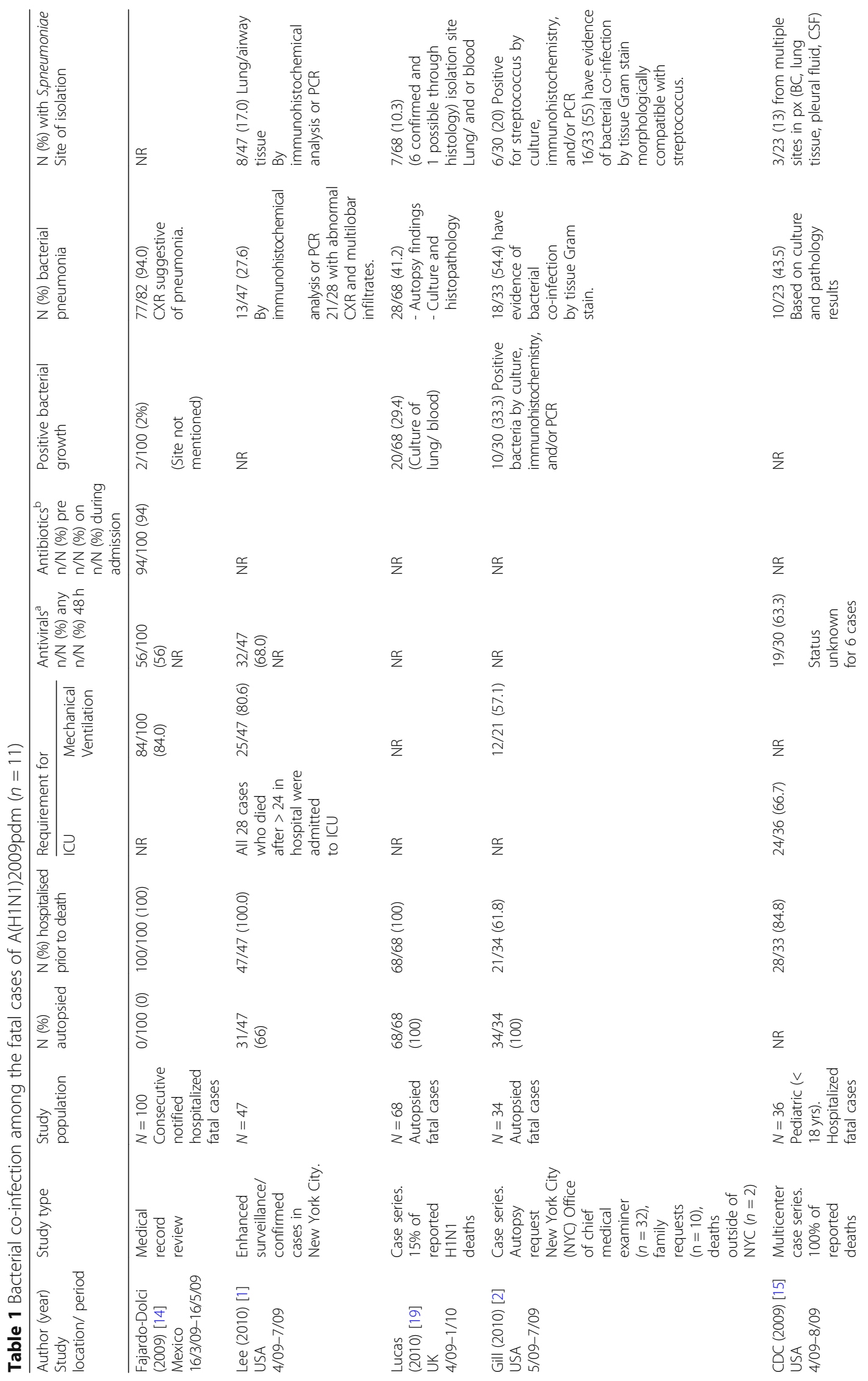




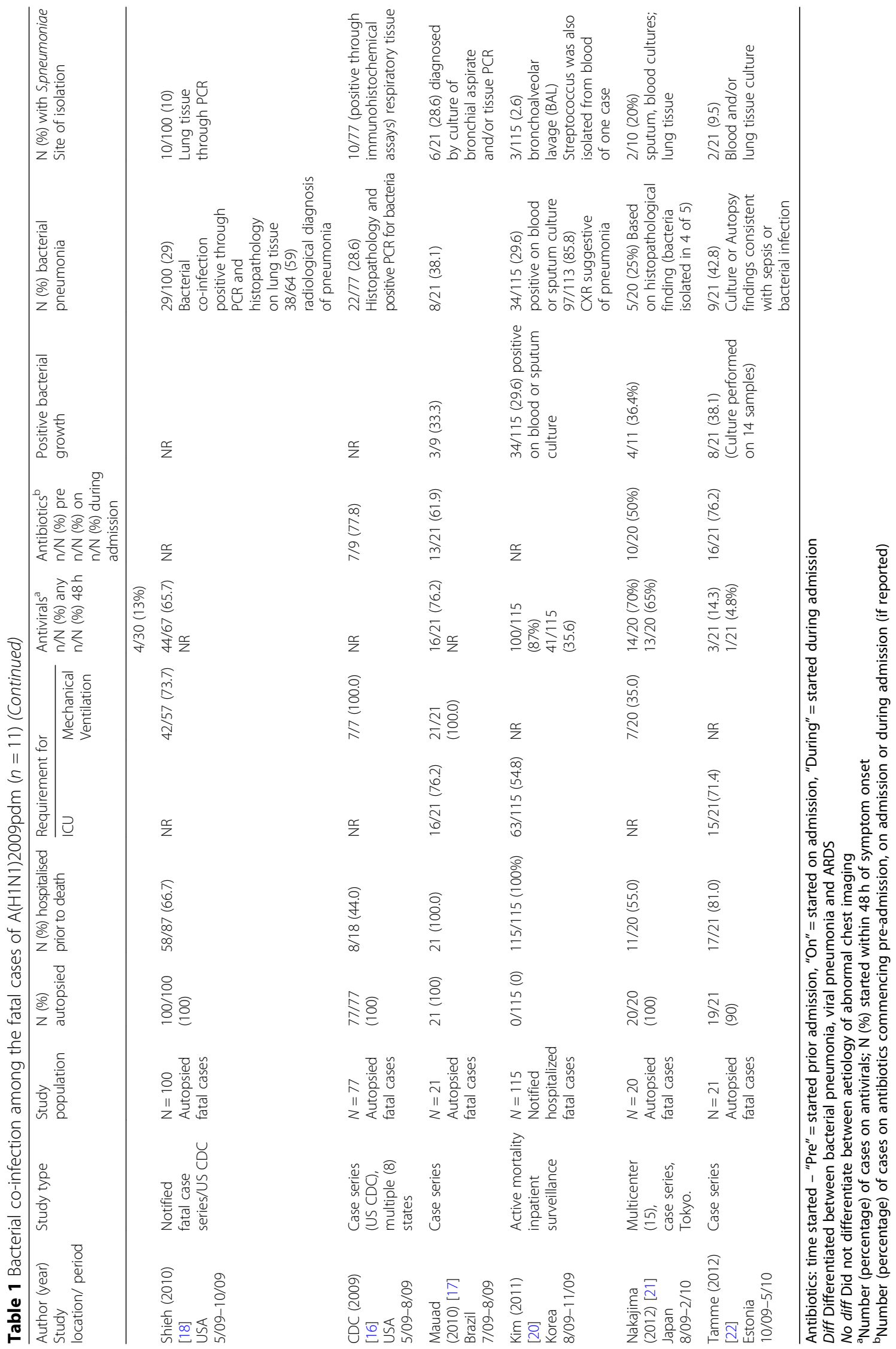




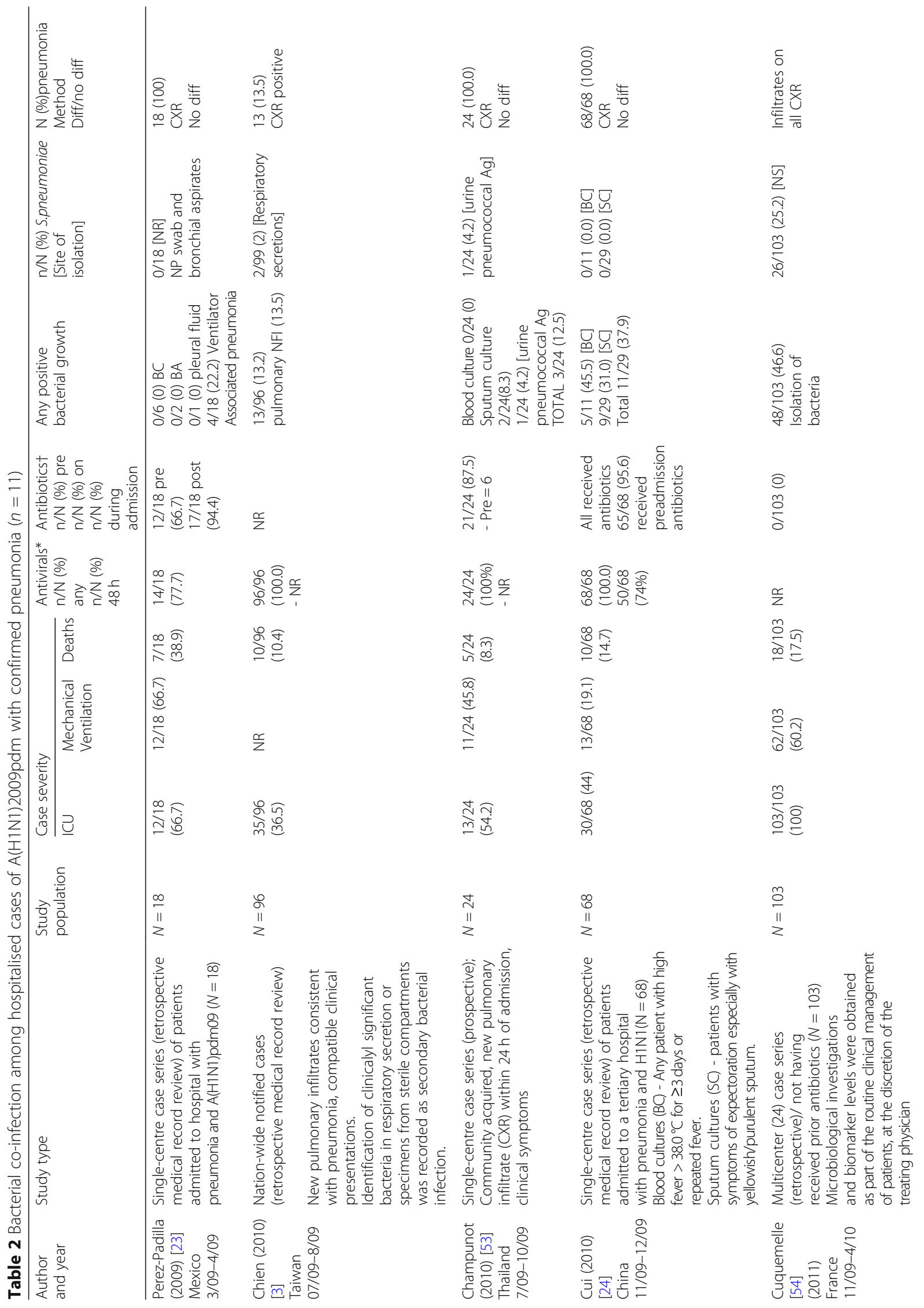




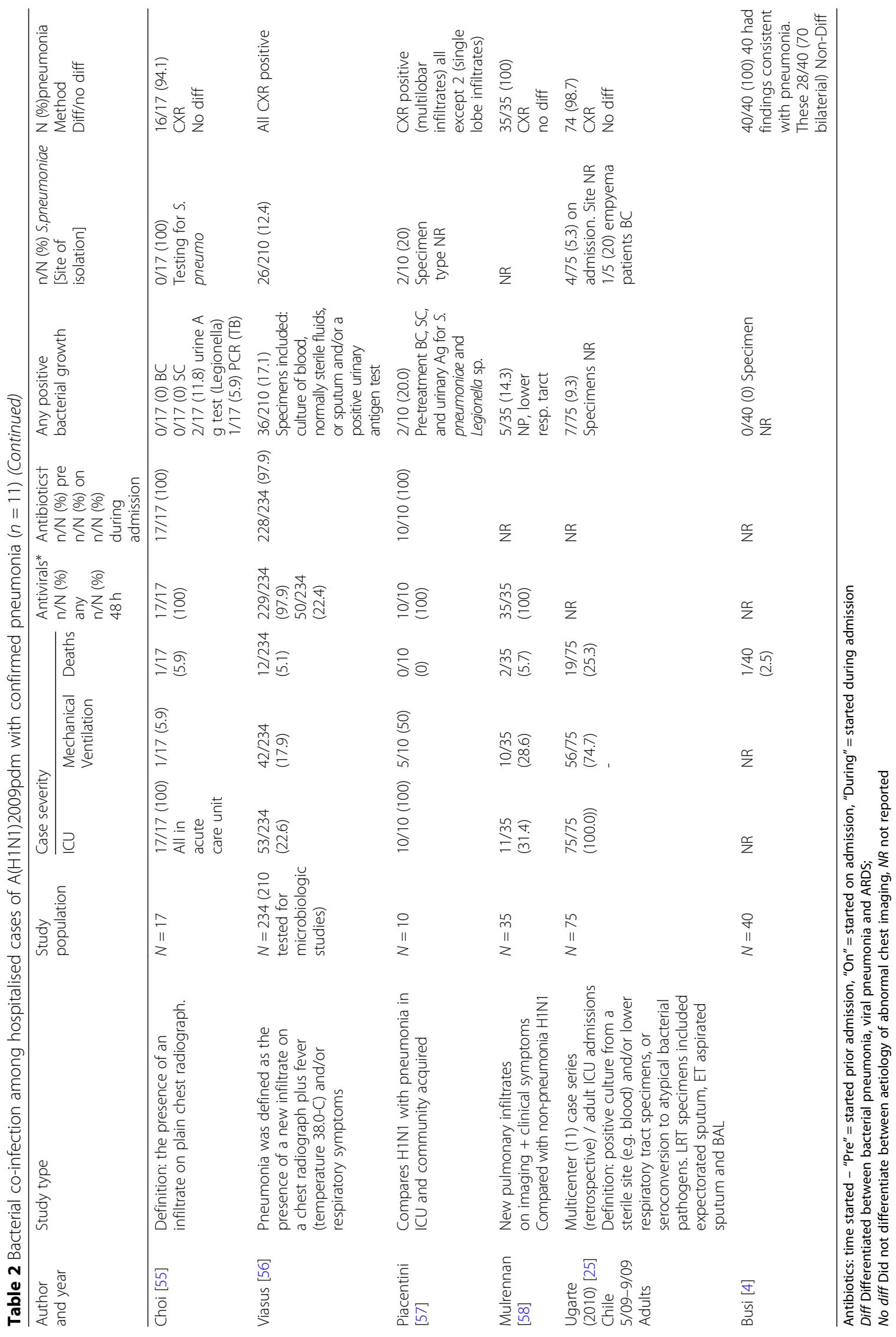




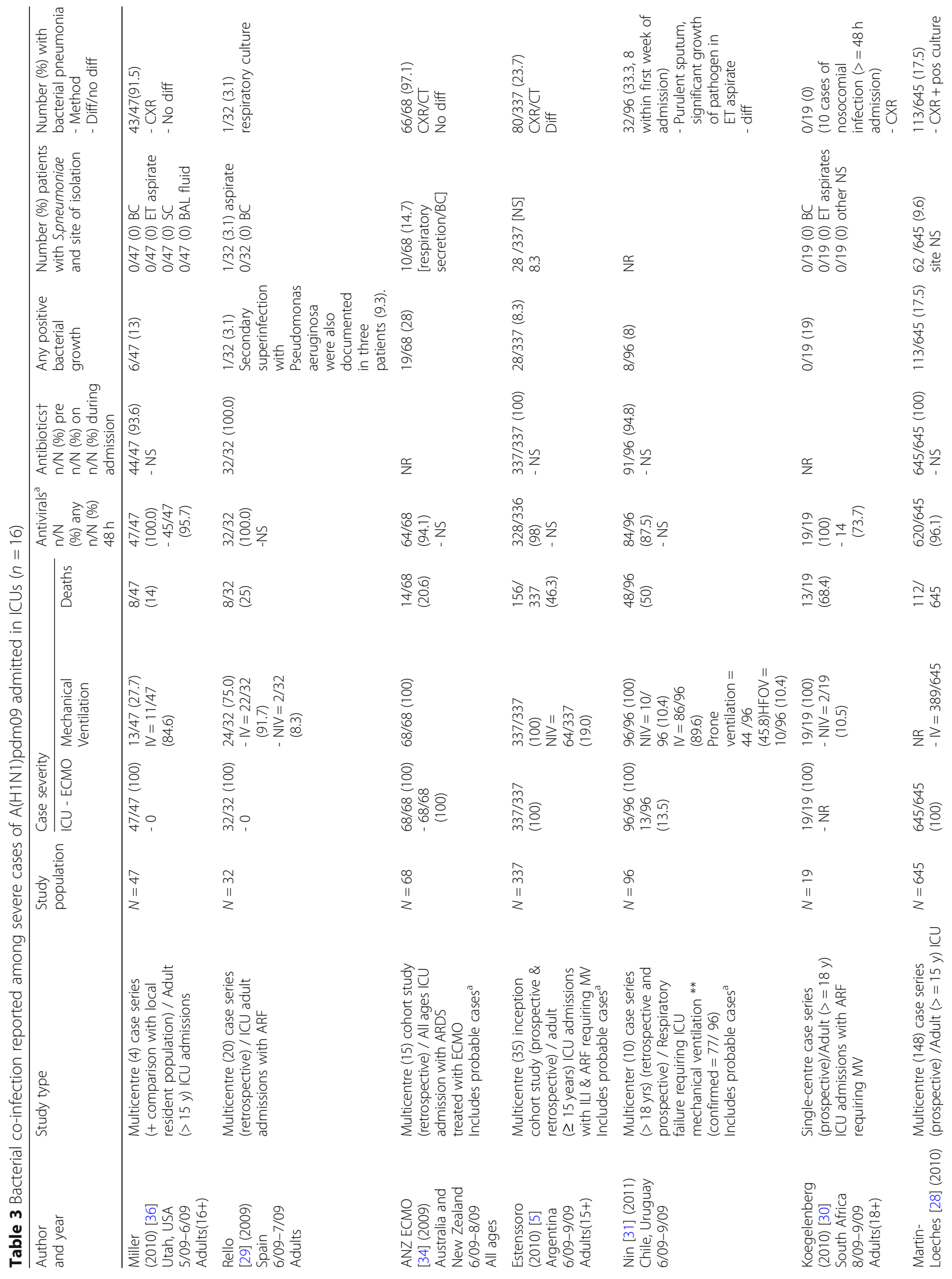




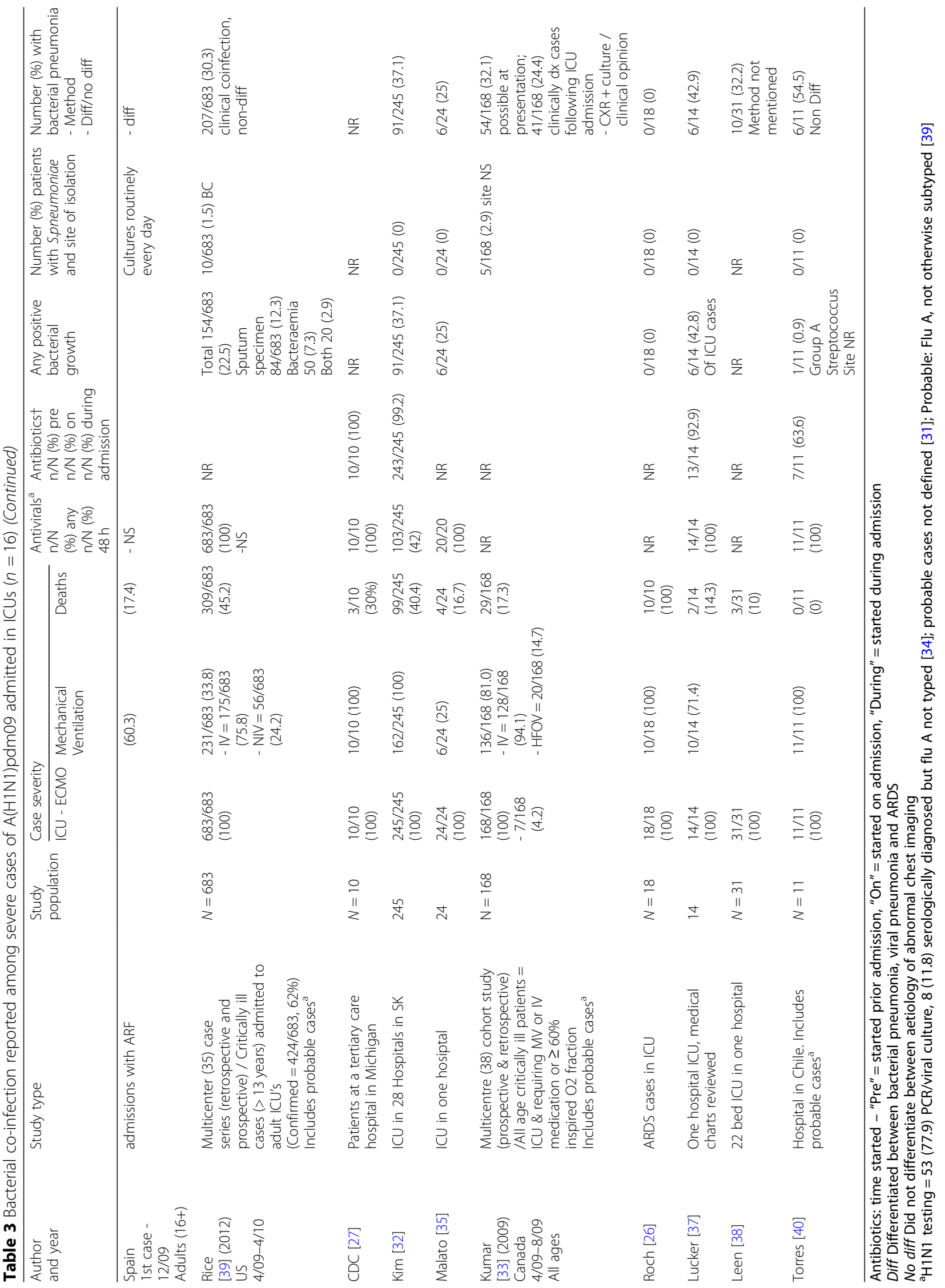




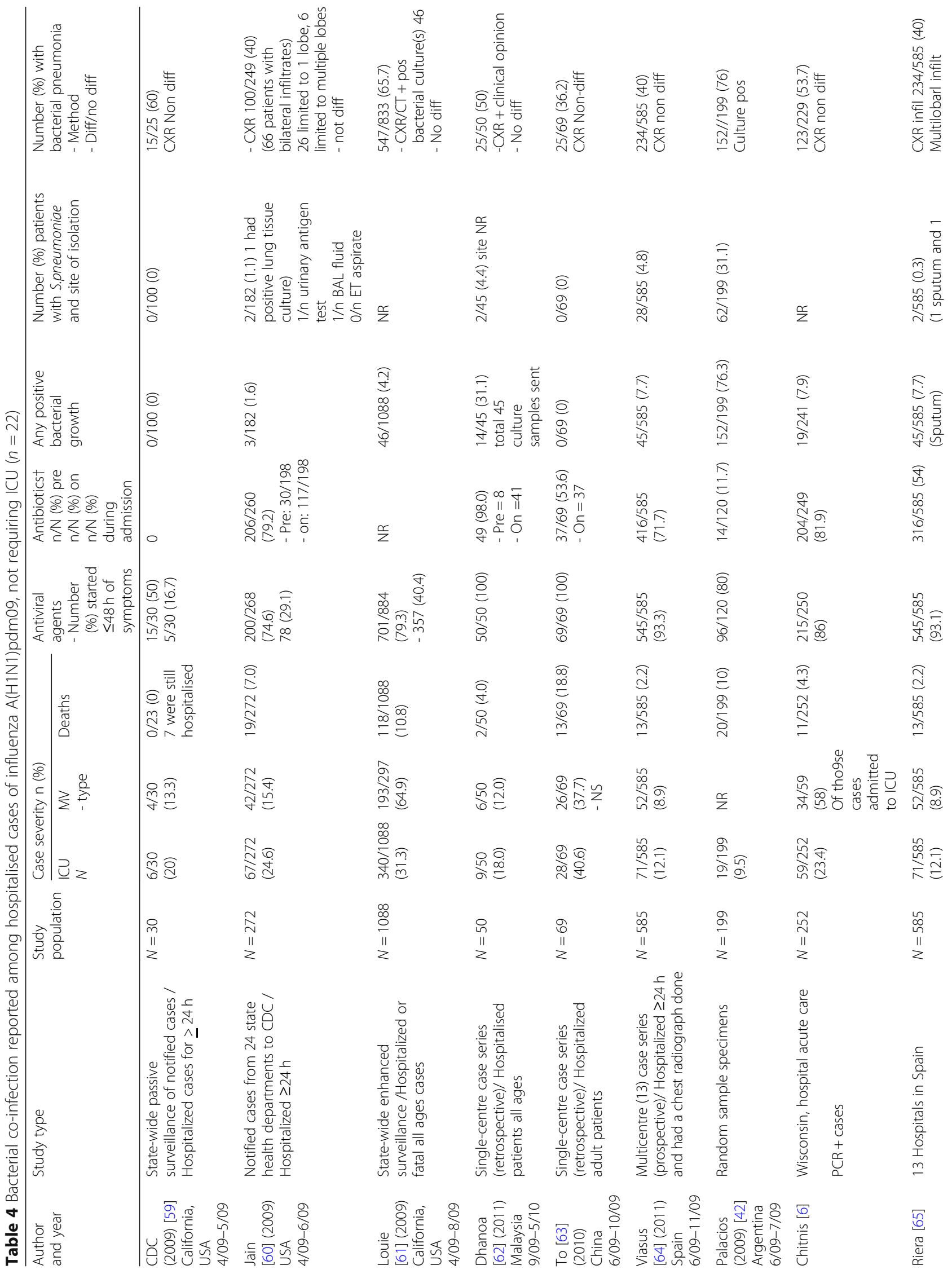




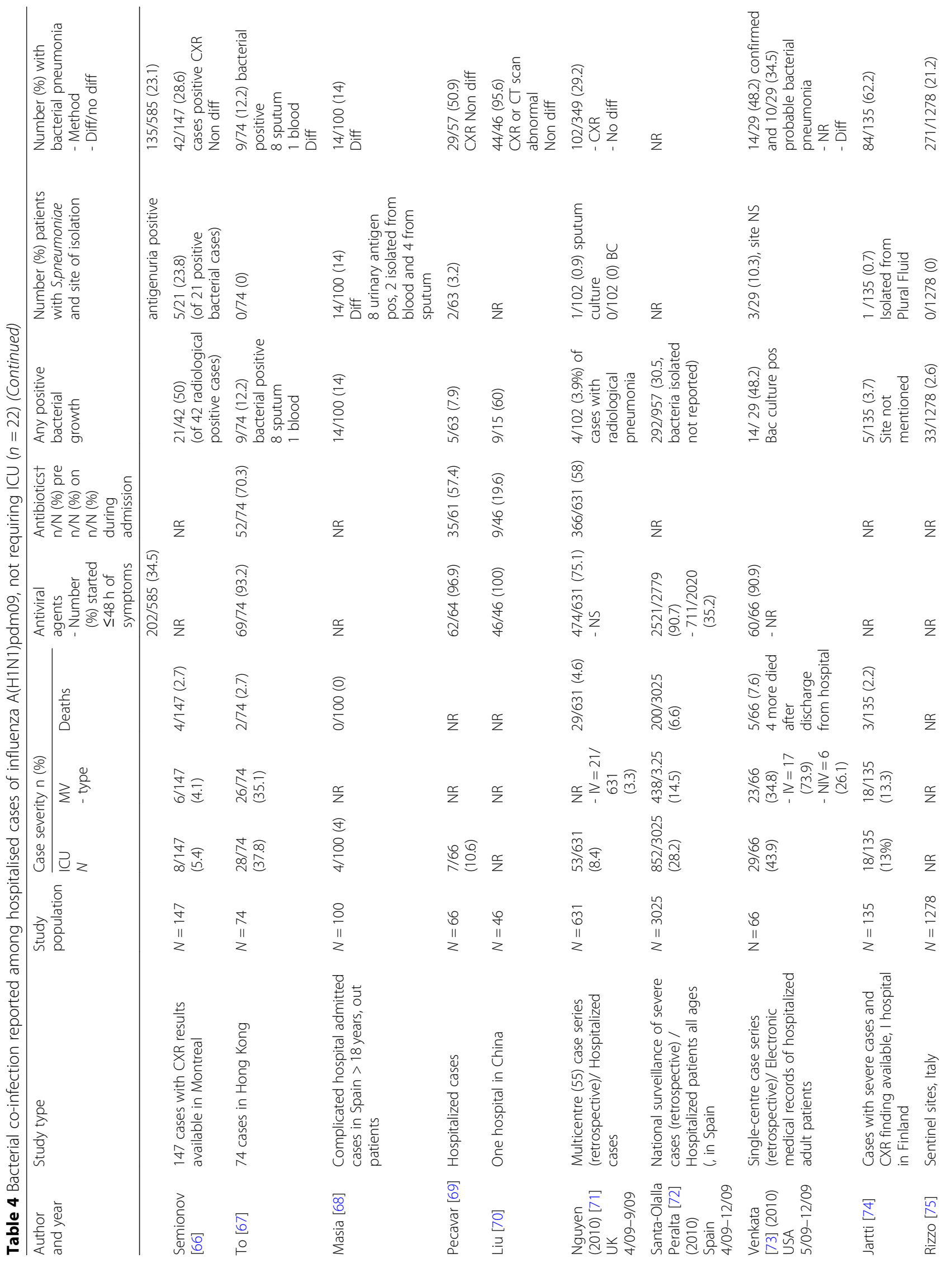




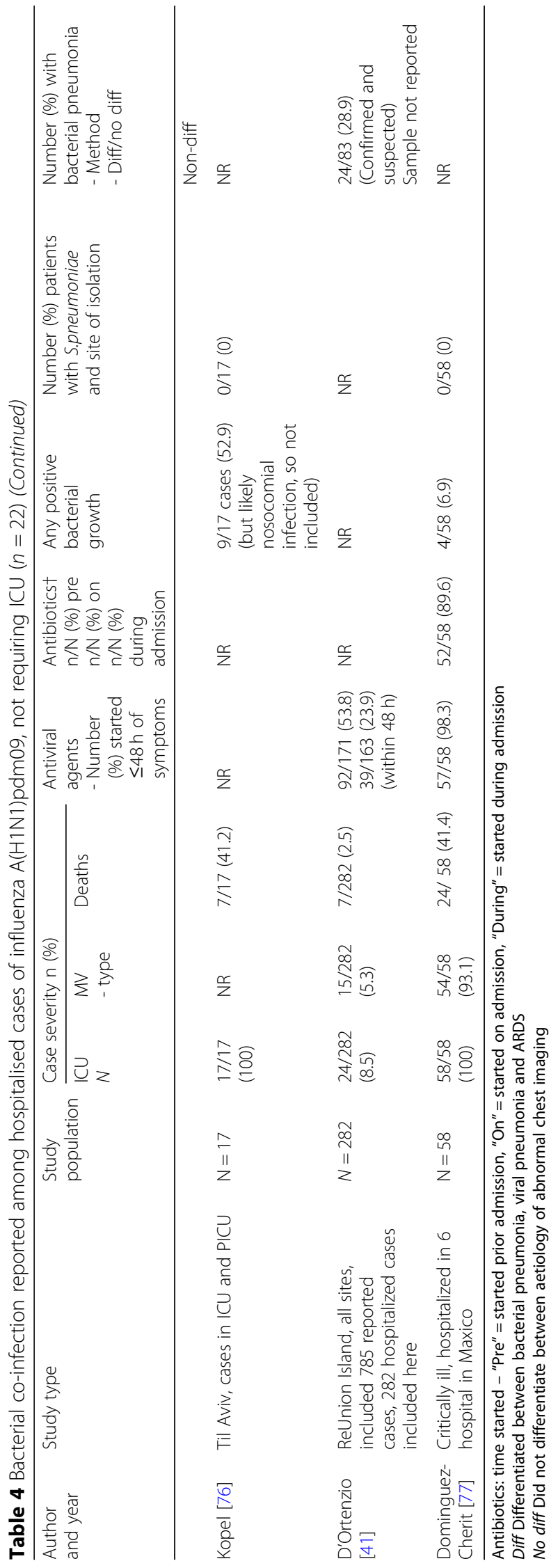


and 6 restricted to PICU and are summarised in Table 5 . The mean prevalence of bacterial co-infection was $16 \%$ in studies of paediatric patients hospitalised in general or pediatric intensive care unit (PICU) wards. Rates of bacterial co-infections vary in these studies, ranging from 0 to $87 \%$ (mean 5\%) in any hospital ward admission to $13-34 \%$ (mean $32 \%$ ) in admission to PICU. The highest rate was reported by Okada [43] who conducted a study in Japan on 46 hospitalised children from July 2009 to January 2010. Bacteria were isolated from nasopharyngeal swabs of $87 \%$ admitted cases (40/46)- S. pneumoniae $37.0 \%$; S. pneumoniae and $\mathrm{H}$. influenzae $23.9 \%$, H. influenza, $26.1 \%$ and S. aureus $23.9 \%$.

\section{Discussion}

Secondary bacterial infection was an important complication of the 2009 influenza pandemic, with almost 1 in 4 severe or fatal cases having bacterial secondary infections, albeit with varying rates. Bacterial infection appeared to be associated with morbidity and mortality, with higher rates in adults, ICU patients and those with a fatal outcome. Streptococcus pneumoniae was the most common bacteria identified, and in ICU patients, ventilator associated pneumonia with organisms such as Acinetobacter baumannii, Achromobacter xylosoxidans, methicillin-resistant Staphylococcus aureus, and Escherichia coli was common. The prevalence of bacterial co-infection was lower in studies of hospitalized patients not requiring ICU and in studies of paediatric hospitalized patients, although the latter was quite varied.

The overall morbidity and mortality of the 2009 pandemic varied by country, but was cited as being similar to a severe seasonal influenza epidemic [44]. However, two important differences in the epidemiologic pattern of the 2009 pandemic were firstly, a low average age of death in fatal cases (53 years compared to 83 years during seasonal influenza) and high intensive care unit (ICU) occupancy rates [45]. These two features hint at a severe population impact, and a UK study showed a "w" shaped morbidity curve with a peak in young adults [46].

The 1918 pandemic has served as a reference point in pandemic planning, but availability of antibiotics, critical care and extra-corporeal membrane oxygenation (ECMO) have vastly improved survival during a contemporary pandemic, so it would be unlikely that case fatality rates of 1918 would recur in the modern era [45]. The use of ECMO rose sharply in 2009 and is associated with high rates of survival [47].

Further, in understanding the morbidity and mortality impact of a modern pandemic, it is important to quantify the relative contribution of direct viral effects compared to bacterial secondary infections, as treatment and prevention options are also available for bacterial infections.
Testing for bacterial complications during an influenza pandemic is important, but was neglected in most studies which we screened for this review. For optimal response and mitigation of preventable morbidity and mortality, active surveillance during both seasonal and pandemic influenza is necessary, and systems should be in place for rapid assessment of secondary bacterial morbidity and mortality. Diagnosis and treatment of secondary bacterial infections should always be considered during a pandemic [10].

Currently there are limited data on bacterial coinfection during influenza pandemic in 1918. Morens et al. reviewed autopsy data from 58 lung tissue samples collected during the 1918 influenza pandemic and histologic evidence of severe bacterial pneumonia was found in almost all samples [10]. The authors also did a literature search around autopsy case series and examined data of 3074 subjects in 68 high quality autopsy case series. This showed that more than $92 \%$ of autopsy lung cultures were positive for at least one bacterium [10]. Another study by Chien et al. reviewed the studies that reported more than 10 sterile-site antemortem cultures from adults with pneumonia during 1918 pandemic [48]. Culture positivity rates among influenza cases without pneumonia was very low (mean $<1 \%$ ), compare to those with pneumonia (mean, 16\%; range, 2 to 50) [48]. Bacterial co-infection rates among hospitalised cases with confirmed pneumonia in this study was $19 \%$, which is comparable to Chien et al.

The rate of bacterial co-infection may be underestimated as many cases are not tested for bacterial infections, and bacterial pneumonia cannot always be differentiated from viral pneumonia on the basis of clinical presentation, radiology and routine blood tests. There is also a need to develop diagnostic algorithms for early identification of bacterial infections in these cases to ensure early detection and treatment of bacterial complications.

The WHO guidelines on vaccines and antivirals for a pandemic, along with many country-specific pandemic plans, do not consider pneumococcal vaccines [49]. The CAPITA trial shows efficacy of conjugate pneumococcal vaccine against pneumonia [50], and the polysaccharide vaccine also has efficacy against invasive pneumococcal disease [51]. We have found evidence that severe and fatal cases of influenza during the 2009 pandemic did comprise secondary bacterial causes, including streptococcus pneumoniae as a contributing factor. Vaccination against streptococcus pneumonia is often neglected in pandemic planning [52], but could have a positive impact on morbidity and mortality. The evidence confirms that prevention of bacterial secondary infection should be an integral part of pandemic planning. Improving uptake of routine pneumococcal vaccination in adults with 


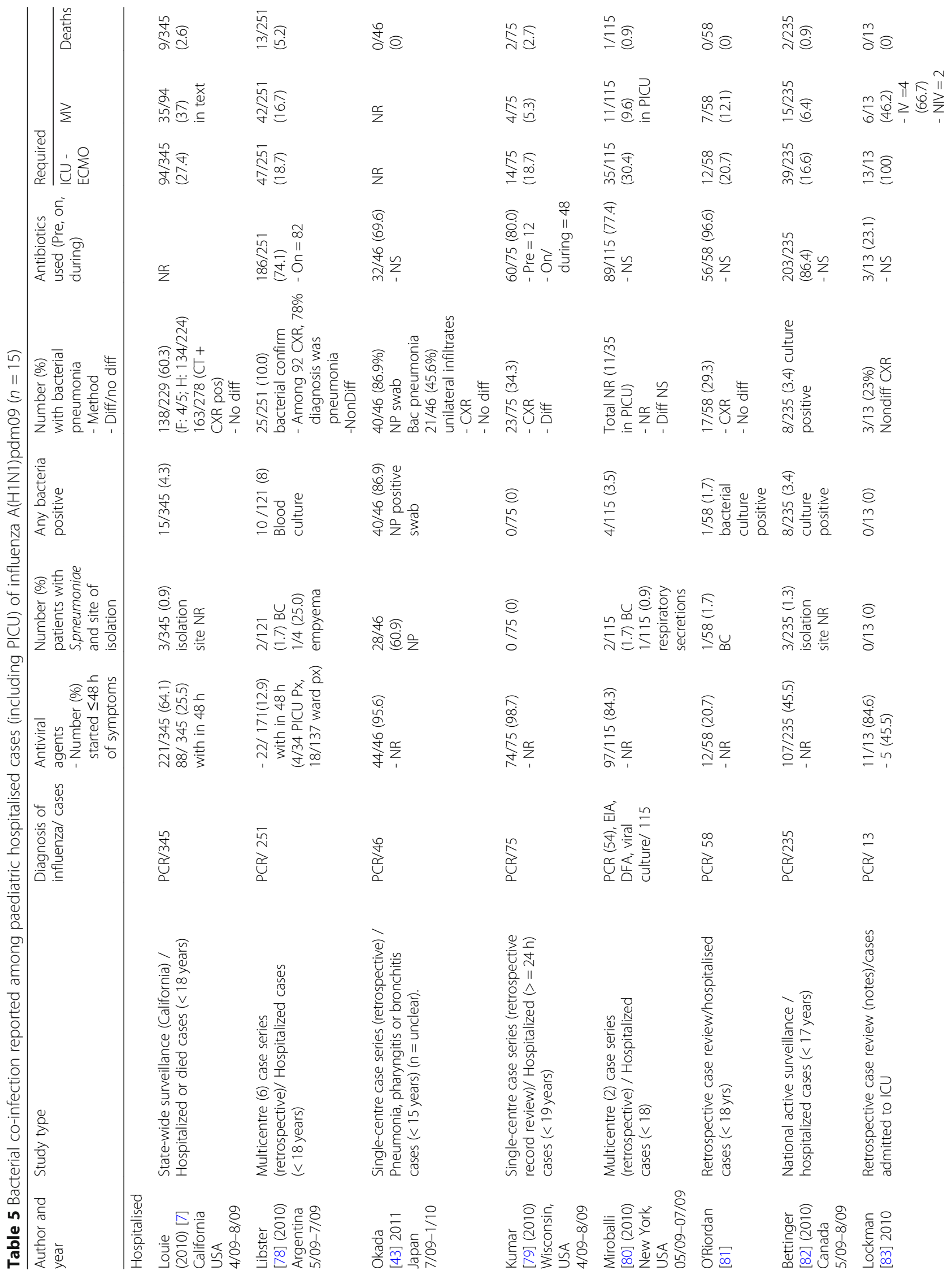




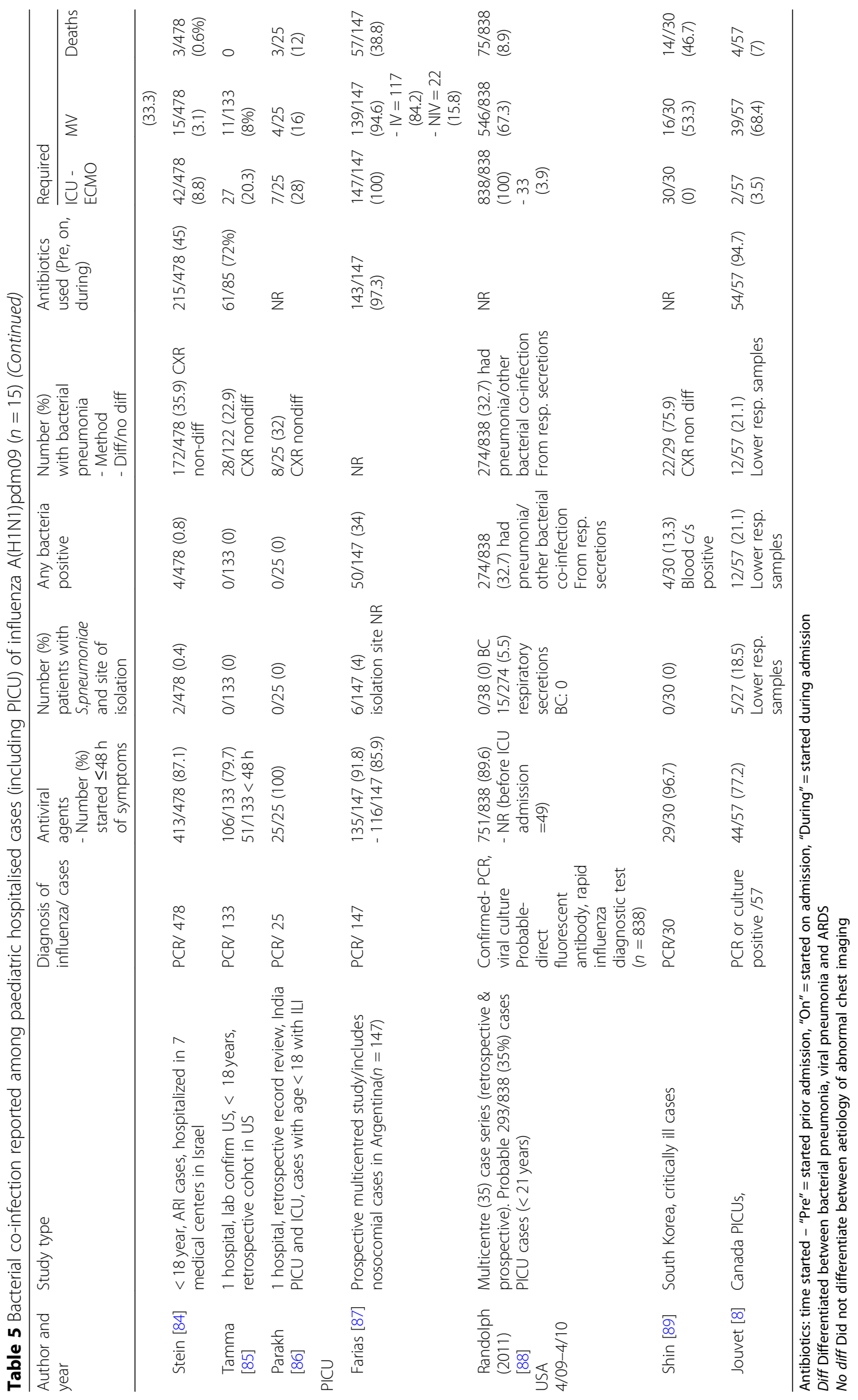


an indication will cover most patients at risk, and may reduce the impact of a pandemic.

To our knowledge, this is the first systematic review to estimate the prevalence of pneumonia and secondary bacterial infections during pandemic influenza $\mathrm{A}(\mathrm{H} 1 \mathrm{~N} 1)$ pdm09. We calculated bacterial co-infection rates separately for fatal cases, hospitalised cases with confirmed pneumonia, hospitalised cases admitted to ICU, hospitalised cases admitted to general wards and paediatric hospitalised cases, showing the highest risk of bacterial infection for fatal and ICU admitted cases.

\section{Conclusion}

We found that secondary bacterial infection was an important complication of the 2009 influenza pandemic, with Streptococcus pneumoniae the most common bacteria identified. Bacterial infection appeared to be associated with morbidity and mortality, with higher rates in adults, ICU patients and those with a fatal outcome. Prevention and treatment of bacterial secondary infection should be an integral part of pandemic planning, and improved uptake of routine pneumococcal vaccination in adults with an indication may reduce the impact of a pandemic.

\section{Abbreviations}

ARDS: Acute respiratory distress syndrome; ARTI: Acute respiratory tract infection; BAL: Bronchoalveolar lavage; BAL: Broncho-alveolar lavage; BC: Blood culture; CT: Computerised tomography; CXR: Chest X-ray; ET: Endotreacheal tube; ICU: Intensive care unit; ILI: Influenza like illness; IV: Invasive ventilation; MeSH: Medical Subject Headings; MV: Mechanical ventilation; NIV: Noninvasive ventilation; NR: Not reported; NS: Not specified; PICU: Pediatric intensive care unit; PRISMA: Preferred Reporting Items for Systematic Reviews; SC: Sputum culture

\section{Acknowledgments}

We acknowledge the support of Anthea Katelaris, Anthony Newall and James Wood for some preliminary work on this project.

\section{Funding}

No funding was involved in this study.

\section{Availability of data and materials}

All data freely available.

\section{Authors' contributions}

CRM: lead investigator, conception and design of the study, drafting and manuscript revision; $A H, M B, R T, I R, H S$ : reviewed the titles and abstracts to identify potentially relevant papers; $A H, M B$ : reviewed all potentially relevant papers to determine those which met the selection criteria and conducted literature review, AAC; reviewed and extracted data from selected paper, prepared first draft of manuscript. All authors approved the final version to be submitted.

\section{Ethics approval and consent to participate} Not applicable.

\section{Consent for publication}

Not applicable.

\section{Competing interests}

C. Raina Maclntyre has received in-kind support and funding for investigator-driven research from GlaxoSmithKline, Pfizer, Merck, and Segirus, and has sat on advisory boards for Merck, GlaxoSmithKline and Pfizer. IR: IR has received grant funds for investigator-driven research from GSK, Pfizer and for consultation from Merck. The remaining authors declare that they have no competing interests and have no non-financial interests that may be relevant to the submitted work.

\section{Publisher's Note}

Springer Nature remains neutral with regard to jurisdictional claims in published maps and institutional affiliations.

\section{Author details}

${ }^{1}$ Biosecurity Program, The Kirby Institute, UNSW Medicine, University of New South Wales, Sydney, NSW 2052, Australia. ${ }^{2}$ School of Public Health and Community Medicine, Faculty of Medicine, UNSW Medicine, the University of New South Wales, Samuels Building, Room 209, Sydney, NSW 2052, Australia.

Received: 27 October 2017 Accepted: 23 November 2018

Published online: 07 December 2018

\section{References}

1. Lee EH, Wu C, Lee EU, et al. Fatalities associated with the 2009 H1N1 influenza A virus in New York city. Clin Infect Dis. 2010;50:1498-504.

2. Gill JR, Sheng ZM, Ely SF, et al. Pulmonary pathologic findings of fatal 2009 pandemic influenza A/H1N1 viral infections. Arch Pathol Lab Med. 2010; 134:235-43

3. Chien YS, Su CP, Tsai HT, et al. Predictors and outcomes of respiratory failure among hospitalized pneumonia patients with 2009 H1N1 influenza in Taiwan. J Inf Secur. 2010;60:168-74.

4. Busi RE, Schinina V, Ferraro F, et al. Radiological findings of pneumonia in patients with swine-origin influenza A virus (H1N1). Radiol Med. 2010;115:507-15.

5. Estenssoro E, Rios FG, Apezteguia C, et al. Pandemic 2009 influenza A in Argentina: a study of 337 patients on mechanical ventilation. Am J Respir Crit Care Med. 2010;182:41-8.

6. Chitnis AS, Truelove SA, Druckenmiller JK, Heffernan RT, Davis JP. Epidemiologic and clinical features among patients hospitalized in Wisconsin with 2009 H1N1 influenza A virus infections, April to August 2009. WMJ. 2010;109:201-8.

7. Louie JK, Gavali S, Acosta M, et al. Children hospitalized with 2009 novel influenza $A(H 1 N 1)$ in California. Arch Pediatr Adolesc Med. 2010;164:1023-31.

8. Jouvet $P$, Hutchison J, Pinto $R$, et al. Critical illness in children with influenza A/pH1N1 2009 infection in Canada. Pediatr Crit Care Med. 2010;11:603-9.

9. Madhi SA, Klugman KP. A role for Streptococcus pneumoniae in virusassociated pneumonia. Nat Med. 2004;10:811-3 Epub 2004/07/13.

10. Morens DM, Taubenberger JK, Fauci AS. Predominant role of bacterial pneumonia as a cause of death in pandemic influenza: implications for pandemic influenza preparedness. J Infect Dis. 2008;198:962-70 Epub 2008/08/20.

11. Brundage JF, Shanks GD. Deaths from bacterial pneumonia during 1918-19 influenza pandemic. Emerg Infect Dis. 2008;14:1193-9 Epub 2008/08/06.

12. Moher D, Liberati A, Tetzlaff J, Altman DG, Group P. Preferred reporting items for systematic reviews and meta-analyses: the PRISMA statement. Int J Surg. 2010;8:336-41.

13. World Health Organisation $(\mathrm{WHO})$. Standardization of terminology of the pandemic $\mathrm{A}(\mathrm{H} 1 \mathrm{N1} 1) 2009$ virus. 2011. Available from: http://www.who.int/ influenza/gisrs_laboratory/terminology_ah1n1pdm09/en/. Cited 24 Jan 2013.

14. Fajardo-Dolci G, Gutierrez-Vega R, Arboleya-Casanova H, et al. Clinical characteristics of fatalities due to influenza A (H1N1) virus in Mexico. Thorax. 2010:65:505-9.

15. Centers for Disease Control and Prevention. Surveillance for pediatric deaths associated with 2009 pandemic influenza A (H1N1) virus infection - United States, April-August 2009. MMWR Morb Mortal Wkly Rep. 2009;58:941-7.

16. Centers for Disease Control and Prevention. Bacterial coinfections in lung tissue specimens from fatal cases of 2009 pandemic influenza A (H1N1) - United States, May-August 2009. MMWR Morb Mortal Wkly Rep. 2009;58:1071-4.

17. Mauad T, Hajjar LA, Callegari GD, et al. Lung pathology in fatal novel human influenza A (H1N1) infection. Am J Respir Crit Care Med. 2010;181:72-9.

18. Shieh W-J, Blau DM, Denison AM, et al. 2009 pandemic influenza A (H1N1): pathology and pathogenesis of 100 fatal cases in the United States. Am J Pathol. 2010:177:166-75.

19. Lucas S. Predictive clinicopathological features derived from systematic autopsy examination of patients who died with $\mathrm{A} / \mathrm{H} 1 \mathrm{~N} 1$ influenza infection in the UK 2009-10 pandemic. Health Technol Assess. 2010;14:83-114.

20. Kim HS, Kim JH, Shin SY, et al. Fatal cases of 2009 pandemic influenza A (H1N1) in Korea. J Korean Med Sci. 2011;26:22-7. 
21. Nakajima N, Sato Y, Katano H, et al. Histopathological and immunohistochemical findings of 20 autopsy cases with 2009 H1N1 virus infection. Mod Pathol. 2012;25:1-13.

22. Tamme K, Minajeva A, Adamson V, et al. Clinical and pathological findings of fatal 2009-2010 pandemic influenza A (H1N1) infection in Estonia. Medicina (Kaunas). 2012;48:48-56.

23. Perez-Padilla R, De La Rosa-Zamboni D, Ponce De Leon S, et al. Pneumonia and respiratory failure from swine-origin influenza $\mathrm{A}(\mathrm{H} 1 \mathrm{~N} 1)$ in Mexico. N Engl J Med. 2009:361:680-9.

24. Cui W, Zhao H, Lu X, et al. Factors associated with death in hospitalized pneumonia patients with 2009 H1N1 influenza in Shenyang, China. BMC Infect Dis. 2010;10:145.

25. Ugarte S, Arancibia F, Soto R. Influenza A pandemics: clinical and organizational aspects: the experience in Chile. Crit Care Med. 2010;38(4 Suppl):e133-7.

26. Roch A, Lepaul-Ercole R, Grisoli D, et al. Extracorporeal membrane oxygenation for severe influenza $\mathrm{A}(\mathrm{H} 1 \mathrm{~N} 1)$ acute respiratory distress syndrome: a prospective observational comparative study. Intensive Care Med. 2010;36:1899-905.

27. Centers for Disease Control and Prevention. Intensive-care patients with severe novel influenza A (H1N1) virus infection - Michigan, June 2009. MMWR Morb Mortal Wkly Rep. 2009;58:749-52.

28. Martin-Loeches I, Sanchez-Corral A, Diaz E, et al. Community-acquired respiratory coinfection in critically ill patients with pandemic 2009 influenza A(H1N1) virus. Chest. 2011;139:555-62.

29. Rello J, Rodriguez A, Ibanez P, et al. Intensive care adult patients with severe respiratory failure caused by Influenza $A(\mathrm{H} 1 \mathrm{~N} 1) \mathrm{v}$ in Spain. Crit Care. 2009;13:R148

30. Koegelenberg CF, Irusen EM, Cooper R, et al. High mortality from respiratory failure secondary to swine-origin influenza A (H1N1) in South Africa. Qjm. 2010;103:319-25.

31. Nin N, Soto L, Hurtado J, et al. Clinical characteristics and outcomes of patients with 2009 influenza $A(H 1 N 1)$ virus infection with respiratory failure requiring mechanical ventilation. J Crit Care. 2011;26:186-92.

32. Kim S-H, Hong S-B, Yun S-C, et al. Corticosteroid treatment in critically ill patients with pandemic influenza A/H1N1 2009 infection: analytic strategy using propensity scores. Am J Respir Crit Care Med. 2011;183:1207-14.

33. Kumar A, Zarychanski R, Pinto R, et al. Critically ill patients with 2009 influenza A(H1N1) infection in Canada. JAMA. 2009;302:1872-9.

34. Australia, New Zealand Extracorporeal Membrane Oxygenation Influenza I, Davies A, et al. Extracorporeal Membrane Oxygenation for 2009 Influenza A(H1N1) acute respiratory distress syndrome. JAMA. 2009;302:1888-95.

35. Malato L, Llavador V, Marmier E, Youssef J, Balick Weber C, Rozé H, Bessede E, Fleury HJ. Pandemic influenza A(H1N1)2009: molecular characterisation and duration of viral shedding in intensive care patients in Bordeaux, southwest France, May 2009 to January 2010. Euro Surveill. 2011;16(4). Available online: http://www.eurosurveillance.org/ViewArticle.aspx?Articleld=19776.

36. Miller IRR, Markewitz BA, Rolfs RT, et al. Clinical findings and demographic factors associated with ICU admission in Utah due to novel 2009 influenza a(H1N1) infection. Chest. 2010;137:752-8.

37. Lucker LM, Kherad O, Iten A, et al. Clinical features and outcome of hospitalised adults and children with the 2009 influenza A H1N1 infection at Geneva's University Hospital. Swiss Med Wkly. 2011;141:w13177.

38. Leen T, Williams TA, Campbell $L$, et al. Early experience with influenza A H1N109 in an Australian intensive care unit. Intensive Crit Care Nurs. 2010; 26:207-14.

39. Rice TW, Rubinson L, Uyeki TM, et al. Critical illness from 2009 pandemic influenza A virus and bacterial coinfection in the United States. Crit Care Med. 2012;40:1487-98.

40. Torres JP, O'Ryan M, Herve B, et al. Impact of the novel influenza A (H1N1) during the 2009 autumn-winter season in a large hospital setting in Santiago, Chile. Clin Infect Dis. 2010;50:860-8.

41. D'Ortenzio E, Renault $P$, Jaffar-Bandjee MC, et al. A review of the dynamics and severity of the pandemic $\mathrm{A}(\mathrm{H} 1 \mathrm{~N} 1)$ influenza virus on Reunion island, 2009. Clin Microbiol Infect. 2010;16:309-16.

42. Palacios G, Hornig M, Cisterna D, et al. Streptococcus pneumoniae coinfection is correlated with the severity of H1N1 pandemic influenza. PLoS One. 2009;4:1-5.

43. Okada T, Morozumi M, Matsubara K, et al. Characteristic findings of pediatric inpatients with pandemic (H1N1) 2009 virus infection among severe and nonsevere illnesses. J Infect Chemother. 2011;17:238-45.
44. Muscatello DJ, Cretikos MA, Macintyre CR. All-cause mortality during first wave of pandemic (H1N1) 2009, New South Wales, Australia, 2009. Emerg Infect Dis. 2010;16:1396-402 Epub 2010/08/26.

45. Bishop JF, Murnane MP, Owen R. Australia's winter with the 2009 pandemic influenza A (H1N1) virus. N Engl J Med. 2009;361:2591-4 Epub 2009/11/27.

46. Myles PR, Semple MG, Lim WS, et al. Predictors of clinical outcome in a national hospitalised cohort across both waves of the influenza $\mathrm{A} / \mathrm{H} 1 \mathrm{~N} 1$ pandemic 2009-2010 in the UK. Thorax. 2012;67:709-17.

47. Bridges B, Rycus P, Fonnesbeck C, Fleming G, Halasa N. Global trends in Extracorporeal membranous Oxygenation use and survival of patients with Influenza-associated illness. Pediatr Crit Care Med. 2016; 17:876-83.

48. Chien Y-W, Klugman KP, Morens DM. Bacterial pathogens and death during the 1918 influenza pandemic. N Engl J Med. 2009:361:2582-3.

49. World Health Organisation (WHO). WHO guidelines on the use of vaccines and antivirals during influenza pandemics. 2004

50. Bonten M, Bolkenbaas M, Huijts S, et al. Community acquired pneumonia immunisation trial in adults (CAPITA). Pneumonia. 2014:3:95.

51. Jackson LA, Neuzil KM, Yu O, et al. Effectiveness of pneumococcal polysaccharide vaccine in older adults. N Engl J Med. 2003;348:1747-55.

52. Itzwerth R. Pandemic influenza and critical infrastructure. Sydney: University of New South Wales (UNSW); 2013.

53. Champunot R, Tanjatham S, Kerdsin A, et al. Impact of pandemic influenza (H1N1) virus-associated community-acquired pneumonia among adults in a tertiary hospital in Thailand. Jpn J Infect Dis. 2010;63:251-6.

54. Cuquemelle E, Soulis F, Villers D, et al. Can procalcitonin help identify associated bacterial infection in patients with severe influenza pneumonia? A multicentre study. Intensive Care Med. 2011;37:796-800.

55. Choi WJ, Kim WY, Kim SH, et al. Clinical characteristics of pneumonia in hospitalized patients with novel influenza A (H1N1) in Korea. Scand J Infect Dis. 2010;42:311-4.

56. Viasus D, Pano-Pardo JR, Pachon J, et al. Pneumonia complicating pandemic (H1N1) 2009: risk factors, clinical features, and outcomes. Medicine (Baltimore). 2011;90:328-36.

57. Piacentini E, Sanchez B, Arauzo V, et al. Procalcitonin levels are lower in intensive care unit patients with H1N1 influenza A virus pneumonia than in those with community-acquired bacterial pneumonia. A pilot study. J Crit Care. 2011;26:201-5

58. Mulrennan S, Tempone SS, Ling ITW, et al. Pandemic influenza (H1N1) 2009 pneumonia: CURB-65 score for predicting severity and nasopharyngeal sampling for diagnosis are unreliable. PLoS One. 2010;5:e12849.

59. Centers for Disease Control. Hospitalized patients with novel influenza A (H1N1) virus infection - California, April-May, 2009. MMWR Morb Mortal Wkly Rep. 2009;58:536-41.

60. Jain S, Kamimoto L, Bramley AM, et al. Hospitalized patients with 2009 H1N1 influenza in the United States, April-June 2009. N Engl J Med. 2009; 361:1935-44.

61. Louie JK, Acosta M, Winter K, et al. Factors associated with death or hospitalization due to pandemic 2009 influenza A(H1N1) infection in California. JAMA. 2009:302:1896-902.

62. Dhanoa A, Fang NC, Hassan SS, Kaniappan P, Rajasekaram G. Epidemiology and clinical characteristics of hospitalized patients with pandemic influenza A (H1N1) 2009 infections: the effects of bacterial coinfection. Virol J. 2011:8:501.

63. To KKW, Wong SSY, Li IWS, et al. Concurrent comparison of epidemiology, clinical presentation and outcome between adult patients suffering from the pandemic influenza A (H1N1) 2009 virus and the seasonal influenza A virus infection. Postgrad Med J. 2010;86:515-21.

64. Viasus D, Pano-Pardo JR, Pachon J, et al. Factors associated with severe disease in hospitalized adults with pandemic (H1N1) 2009 in Spain. Clin Microbiol Infect. 2011;17:738-46

65. Riera M, Payeras A, Marcos MA, et al. Clinical presentation and prognosis of the 2009 H1N1 influenza A infection in HIV-1-infected patients: a Spanish multicenter study. Aids. 2010;24:2461-7

66. Semionov A, Tremblay C, Samson L, et al. Pandemic influenza A (H1N1) 2009: chest radiographic findings from 147 proven cases in the Montreal area. Can Assoc Radiol J. 2010;61:233-40.

67. To KKW, Hung IFN, Li IWS, et al. Delayed clearance of viral load and marked cytokine activation in severe cases of pandemic H1N1 2009 influenza virus infection. Clin Infect Dis. 2010;50:850-9. 
68. Masia M, Padilla S, Antequera P, et al. Predictors of pneumococcal coinfection for patients with pandemic (H1N1) 2009. Emerg Infect Dis. 2011; 17:1475-8.

69. Pecavar B, Nadrah K, Papst L, et al. Clinical characteristics of adult patients with influenza-like illness hospitalized in general ward during Influenza A H1N1 pandemic 2009/2010. Wien Klin Wochenschr. 2011;123:662-7.

70. Liu Y, Chen H, Sun Y, Chen F. Antiviral role of toll-like receptors and cytokines against the new $2009 \mathrm{H} 1 \mathrm{~N} 1$ virus infection. Mol Biol Rep. 2012;39:1163-72.

71. Nguyen-Van-Tam JS, Openshaw PJM, Hashim A, et al. Risk factors for hospitalisation and poor outcome with pandemic A/H1N1 influenza: United Kingdom first wave (May-September 2009). Thorax. 2010;65:645-51.

72. Santa-Olalla Peralta P, Cortes-Garcia M, Vicente-Herrero M, et al. Risk factors for disease severity among hospitalised patients with 2009 pandemic influenza A (H1N1) in Spain, April - December 2009. Euro Surveill. 2010;15:23.

73. Venkata C, Sampathkumar P, Afessa B. Hospitalized patients with 2009 H1N1 Influenza infection: the Mayo Clinic experience. Mayo Clin Proc. 2010;85: 798-805.

74. Jartti A, Rauvala E, Kauma H, et al. Chest imaging findings in hospitalized patients with H1N1 influenza. Acta Radiol. 2011;52:297-304.

75. Rizzo C, Caporali MG, Rota MC. Pandemic influenza and pneumonia due to legionella pneumophila: a frequently underestimated coinfection. Clin Infect Dis. 2010;51:115.

76. Kopel E, Amitai Z, Grotto I, Kaliner E, Volovik I. Patients with pandemic (H1N1) 2009 in intensive care units, Israel. Emerg Infect Dis. 2010;16:720-1.

77. Dominguez-Cherit G, Lapinsky SE, Macias AE, et al. Critically ill patients with 2009 influenza A(H1N1) in Mexico. JAMA. 2009:302:1880-7.

78. Libster R, Bugna J, Coviello S, et al. Pediatric hospitalizations associated with 2009 pandemic influenza A (H1N1) in Argentina. N Engl J Med. 2010; 362:45-55.

79. Kumar S, Havens PL, Chusid MJ, et al. Clinical and epidemiologic characteristics of children hospitalized with 2009 pandemic H1N1 influenza a infection. Pediatr Infect Dis J. 2010;29:591-4.

80. Miroballi Y, Baird JS, Zackai S, et al. Novel influenza $\mathrm{A}(\mathrm{H} 1 \mathrm{~N} 1)$ in a pediatric health care facility in New York City during the first wave of the 2009 pandemic. Arch Pediatr Adolesc Med. 2010;164:24-30.

81. O'Riordan S, Barton M, Yau Y, et al. Risk factors and outcomes among children admitted to hospital with pandemic H1N1 influenza. CMAJ. 2010; 182:39-44.

82. Bettinger JA, Sauve LJ, Scheifele DW, et al. Pandemic influenza in Canadian children: a summary of hospitalized pediatric cases. Vaccine. 2010;28:3180-4.

83. Lockman JL, Fischer WA, Perl TM, Valsamakis A, Nichols DG. The critically ill child with novel H1N1 influenza A: a case series. Pediatr Crit Care Med. 2010;11:173-8.

84. Stein M, Tasher D, Glikman D, et al. Hospitalization of children with influenza A(H1N1) virus in Israel during the 2009 outbreak in Israel: a multicenter survey. Arch Pediatr Adolesc Med. 2010;164:1015-22.

85. Tamma PD, Turnbull AE, Milstone AM, et al. Clinical outcomes of seasonal influenza and pandemic influenza A (H1N1) in pediatric inpatients. BMC Pediatr. 2010;10:72

86. Parakh A, Kumar A, Kumar V, Dutta AK, Khare S. Pediatric hospitalizations associated with 2009 pandemic influenza A (H1N1): an experience from a tertiary care center in North India. Indian J Pediatr. 2010;77:981-5.

87. Farias JA, Fernandez A, Monteverde E, et al. Critically ill infants and children with influenza $\mathrm{A}(\mathrm{H} 1 \mathrm{~N} 1)$ in pediatric intensive care units in Argentina. Intensive Care Med. 2010;36:1015-22.

88. Randolph AG, Vaughn F, Sullivan $R$, et al. Critically ill children during the 2009-2010 influenza pandemic in the United States. Pediatrics. 2011; 128:e1450-8

89. Shin SY, Kim JH, Kim HS, et al. Clinical characteristics of Korean pediatric patients critically ill with influenza A (H1N1) virus. Pediatr Pulmonol. 2010:45:1014-20

Ready to submit your research? Choose BMC and benefit from:

- fast, convenient online submission

- thorough peer review by experienced researchers in your field

- rapid publication on acceptance

- support for research data, including large and complex data types

- gold Open Access which fosters wider collaboration and increased citations

- maximum visibility for your research: over $100 \mathrm{M}$ website views per year

At BMC, research is always in progress.

Learn more biomedcentral.com/submissions 